\title{
Hubungan Waktu Belajar di Luar Jam Sekolah dengan Hasil Belajar Fisika di SMA Negeri 2 Mataram
}

\section{Gusti Afifah $^{1}$, Syahrial A $^{2 *}$, Jannatin Ardhuha ${ }^{3}$, I Nyoman Sri Putu Verawati ${ }^{4}$}

1) SMA Negeri 2 Mataram, Jl. Panji Tilar Negara No. 25 Mataram, Indonesia 83115

2) 3) 4)5) Program Studi Pendidikan Fisika, PMIPA, Universitas Mataram, Jl. Majapahit 62

Mataram, Indonesia 83125

\section{Email: syahrial_ayub@unram.ac.id}

\begin{tabular}{|c|c|}
\hline Article Info & Abstract \\
\hline $\begin{array}{l}\text { Article History } \\
\text { Received: } 29 \text { March } 2020 \\
\text { Revised: } 30 \text { April } 2020 \\
\text { Published: } 15 \text { June } 2020\end{array}$ & \multirow{2}{*}{$\begin{array}{l}\text { This study aims to analyze the relationship between study time outside school } \\
\text { hours with physics learning outcomes of students of SMA Negeri } 2 \text { Mataram. } \\
\text { This type of research is a descriptive study by interpreting the data as it is. } \\
\text { Learning time data collection outside of school hours is obtained through a } \\
\text { questionnaire or card that is filled in every day as students study the subject of } \\
\text { waves and optics. Data on physics learning outcomes are obtained by multiple } \\
\text { choice tests. The data is processed by the product moment correlation formula, } \\
\text { followed by a test of the significance of the correlation coefficient. Data } \\
\text { analysis conducted there was a significant relationship between study time } \\
\text { outside school hours with physics learning outcomes of students of SMA } N 2 \\
\text { Mataram with rhitung }=0.96 \text { and rabel = } 0.32 \text { for a significance level of } 5 \% \text {. The } \\
\text { percentage of study time outside of school hours independently is greater than } \\
\text { in a guided manner. The implication of the results of this study is the teacher } \\
\text { obtains a picture of student learning time outside school hours. This picture } \\
\text { can be used as a basis for planning further learning to be more effective and } \\
\text { optimal. }\end{array}$} \\
\hline $\begin{array}{l}\text { Keywords } \\
\text { study time outside school } \\
\text { hours, physics learning } \\
\text { outcomes, high school } 2 \\
\text { mataram }\end{array}$ & \\
\hline Informasi Artikel & Abstrak \\
\hline $\begin{array}{l}\text { Sejarah Artikel } \\
\text { Diterima: } 29 \text { Maret } 2020 \\
\text { Direvisi: } 30 \text { April } 2020 \\
\text { Dipublikasi: } 15 \text { Juni } 2020\end{array}$ & \multirow{2}{*}{$\begin{array}{l}\text { Penelitian ini bertujuan untuk menganalisis hubungan waktu belajar di luar jam } \\
\text { sekolah dengan hasil belajar fisika siswa SMA Negeri } 2 \text { Mataram. Jenis } \\
\text { penelitian ini adalah penelitian deskriptif dengan menginterpretasikan data apa } \\
\text { adanya. Pengumpulan data waktu belajar di luar jam sekolah diperoleh melalui } \\
\text { angket atau kartu isian yang diisi setiap hari selama siswa belajar pokok } \\
\text { bahasan gelombang dan optik. Data hasil belajar fisika didapatkan dengan tes } \\
\text { pilihan ganda. Data diolah dengan rumus korelasi product moment yang } \\
\text { dilanjutkan dengan uji keberartian koefisien korelasi. Analisis data yang } \\
\text { dilakukan terdapat hubungan yang berarti antara waktu belajar di luar jam } \\
\text { sekolah dengan hasil belajar fisika siswa SMA N } 2 \text { Mataram dengan } \mathrm{r}_{\text {hitung }=0,96} \\
\text { dan } \mathrm{r}_{\text {tabel }}=0,32 \text { untuk taraf signifikansi } 5 \% \text {. Prosentase waktu belajar diluar jam } \\
\text { sekolah secara mandiri lebih besar dari pada secara terbimbing. Implikasi hasil } \\
\text { penelitian ini adalah guru memperoleh gambaran tentang waktu belajar siswa } \\
\text { diluar jam sekolah. Gambaran ini dapat dijadikan dasar untuk merencanakan } \\
\text { pembelajaran selanjutnya supaya lebih efektif dan optimal. }\end{array}$} \\
\hline $\begin{array}{l}\text { Kata kunci } \\
\text { waktu belajar di luar jam } \\
\text { sekolah, hasil belajar } \\
\text { fisika, sma negeri } 2 \\
\text { mataram }\end{array}$ & \\
\hline & \\
\hline
\end{tabular}




\section{PENDAHULUAN}

SMA Negeri 2 Mataram sebagai salah satu unit pendidikan yang berkomitmen memajukan pendidikan di Mataram. Untuk mencapai tujuan di atas SMA Negeri 2 Mataram selalu melakukan pembaharuan, inovasi dan kreatifitas dalam melaksanakan kurikulum 2013. Kurikulum 2013 menekankan aktifitas siswa dalam belajar (Hilmi, 2017). Pendekatan saintifik menjadi senjata utama untuk mencapai tujuan pendidikan nasional. Sesuai dengan tuntutan kurikulum, siswa harus lebih banyak belajar diluar jam sekolah dari pada melakukan kegiatan lainnya karena waktu tatap muka dengan guru di sekolah untuk belajar itu terbatas (Ismawati, 2016). Pembelajaran yang diharapkan adalah pembelajaran yang membuat siswa aktif dan bekerja sendiri (Klinger, 1997). Arif Furkan (1982) mengatakan bahwa sesungguhnya kewajiban utama seorang siswa adalah belajar disamping membantu orang tuanya di rumah. Waktu yang ada dapat dimanfaatkan dengan cara membuat jadwal belajar sesuai dengan keadaan seperti bahan yang akan dipelajari, tingkat kesukaran bahan pelajaran dan waktu yang dibutuhkan untuk setiap kali melakukan kegiatan belajar (Abidin, 2014). Banyak siswa yang mengeluh karena kekurangan atau tidak punya waktu belajar untuk menyelesaikan tugas-tugas sekolah (Afifah, 1994). Keadaan ini selalu membuat siswa bingung dan ragu-ragu untuk menetapkan apa yang harus dikerjakan atau dipelajari terlebih dahulu. Djamarah (2005) mengatakan siswa gagal studinya dengan alasan kesulitan waktu untuk belajar, ternyata karena tidak dapat memilih waktu yang tepat diantara kesibukan didalam keluarganya. Berdasarkan uraian tentang cara memanfaatkan waktu dan masalahmasalah belajar yang berhubungan dengan pemanfaatan waktu di atas, maka peneliti merasa perlu untuk melakukan penelitian tentang waktu belajar di luar jam sekolah dan hubungannya dengan hasil belajar fisika di SMA Negeri 2 Mataram. Jadi yang menjadi pertanyaan, adalah apakah terdapat hubungan antara waktu belajar di luar jam sekolah dengan hasil belajar fisika siswa SMA Negeri 2 Mataram?. Rendahnya hasil belajar bidang studi fisika dapat mengurangi kepercayaan masyarakat terhadap kemampuan guru guru fisika, oleh karena itu jalan keluarnya harus dicari. Salah satunya dengan melakukan penelitian ini. Hasil penelitian nantinya akan digunakan sebagai pedoman dan tambahan wawasan bagi siswa untuk mendapatkan hasil belajar yang baik. Huda (2013) mengatakan terdapat banyak faktor yang mempengaruhi hasil belajar siswa, diantaranya faktor guru, siswa dan sarana prasarana. Dalam penelitian ini, penulis fokus pada siswanya dengan melihat waktu belajar mereka di luar jam sekolah. Gambaran waktu belajar siswa diluar jam sekolah akan menjadi pedoman bagi guru dalam merencanakan pembelajaran selanjutnya supaya lebih efektif dan optimal. Penelitian ini juga memberikan masukan dan rekomendasi pada guru dalam melakukan dan meningkatkan kualitas pembelajarannya. Pada saat ini terdapat banyak model pembelajaran yang mendukung penelitian ini. Model pembelajaran proyek adalah pembelajaran yang memberikan kemandirian bagi siswa dalam merencanakan kegiatan untuk menjawab permasalahan, melakukan kegiatan dan memperoleh kesimpulan dari kegiatan yang dilakukan. Model ini, sesuai dikembangkan dan direkomendasikan pada guru dalam merencakan pembelajaran karena berhubungan dengan pembelajaran di luar jam sekolah.

\section{METODE}

Penelitian ini bertujuan untuk menganalisis hubungan waktu belajar di luar jam sekolah dengan hasil belajar fisika siswa SMA Negeri 2 Mataram. Jenis penelitiannya adalah penelitian deskriptif karena mendeskripsikan dan menginterprestasikan data sebagaimana adanya. Data yang diperoleh akan dianalisis dan interpretasikan sesuai dengan tujuan penelitian dan hipotesis penelitian yang akan diuji kebenarannya (Sudjana, 1989). Populasi penelitian ini adalah semua siswa kelas XI SMA Negeri 2 Mataram. Sampel adalah sejumlah individu yang merupakan wakil dari populasi. Untuk menetapkan berapa jumlah sampel yang representatif tidak ada ketentuan yang terlalu mengikat (Muh.Makhrus, 2019). Menentukan proporsi sampel yang akan diambil perlu dipertimbangkan apakah tujuan penelitian tercapai 
atau tidak. Berdasarkan hal ini, sampel penelitiannya adalah XI MIPA7 yang terdiri dari 38 orang siswa. Instrumen yang digunakan dalam penelitian ini adalah (1) alat untuk menentukan waktu belajar di luar jam sekolah yang berupa kartu isian. Afifah (1994) membagi kartu isian waktu belajar di luar jam sekolah ini menjadi 3 waktu, yaitu pagi, siang dan malam. Pada masing-masing waktu ini Afifah (1994) dibagi menjadi belajar sendiri dan belajar terbimbing. Alat ukur ini disusun sendiri berdasarkan informasi yang ingin diperoleh, yaitu jumlah jam belajar siswa diluar sekolah secara mandiri dan terbimbing, seperti yang dilihat pada tabel 1 berikut ini,

Tabel 1 : Kartu Isian Waktu Belajar Siswa di Luar Jam Sekolah

\begin{tabular}{|c|c|c|c|c|c|c|c|}
\hline \multirow[t]{2}{*}{$\begin{array}{l}\text { Waktu } \\
\text { (menit) }\end{array}$} & \multirow{2}{*}{$\begin{array}{l}\text { Belajar } \\
\text { Sendiri } \\
\text { (menit) }\end{array}$} & \multicolumn{5}{|c|}{$\begin{array}{l}\text { Belajar Terbimbing } \\
\text { (menit) }\end{array}$} & \multirow{2}{*}{$\begin{array}{l}\text { Total } \\
\text { Jam } \\
\text { (menit) }\end{array}$} \\
\hline & & Les & $\begin{array}{c}\text { Dengan } \\
\text { Kakak }\end{array}$ & $\begin{array}{c}\text { Dengan } \\
\text { Teman }\end{array}$ & $\begin{array}{c}\text { Dengan } \\
\text { Orang Tua }\end{array}$ & $\begin{array}{c}\text { Lain2 } \\
\text { (sebutkan) }\end{array}$ & \\
\hline Pagi & .................. & …........... & …............ & ..... & …............ & ….............. & ....... \\
\hline Siang & ................... & ............... & ................ & ................ & ................ & ................. & …............. \\
\hline Malam & ............... & .............. & ............... & ............... & ................ & ................. & ................ \\
\hline Jumlah & ................ & ............... & ................. & ............... & ............... & ................. & ……....... \\
\hline
\end{tabular}

(Afifah, 1994)

Pada angket ini diminta mengisi waktu belajar di luar sekolah dalam hitungan menit kemudian jumlahnya dijadikan jam. Jumlah waktu belajar di luar jam sekolah (satuan jam) digunakan untuk menentukan waktu belajar siswa di luar jam sekolah, (2) tes hasil belajar fisika yang disusun berdasarkan materi dalam pokok bahasan gelombang dan optik. Tes dibuat dalam bentuk objektif dengan 5 pilihan. Jumlah tes ini 50 soal yang terdiri dari 25 soal (butir 1 sampai 25) untuk gelombang dan 25 soal (butir 26 sampai 50) untuk optik. Tes ini dikembangkan oleh tim peneliti berdasarkan pada buku fisika SMA karangan Marten Kanginan (2019). Sesuai dengan tujuan penelitian untuk melihat sejauh mana hubungan antara waktu belajar di luar jam sekolah dengan hasil belajar fisika, teknik analisa data yang digunakan adalah teknik korelasi yang dikembangkan oleh Pearson yang disebut dengan teknik korelasi product moment. Menurut Sugiyono (2013) ada tiga syarat yang harus dipenuhi sebelum menggunakan rumus korelasi product moment yaitu, 1) sampel diambil secara random, 2) hubungan antara variabel merupakan hubungan garis lurus (hubungan linier), dan 3) bentuk distribusi variabel adalah distribusi normal. Rumus yang digunakan adalah,

$$
r_{x y}=\frac{n \sum x y-\left(\sum x\right)\left(\sum y\right)}{\sqrt{\left[n\left(\sum x^{2}\right)-\left(\sum x\right)^{2}\right]\left[n\left(\sum y^{2}\right)-\left(\sum y\right)^{2}\right]}}
$$

dimana $\mathrm{x}$ dan y adalah variabel-variabel yang ada di penelitian, yaitu $\mathrm{x}$ adalah jumlah waktu belajar di luar jam sekolah, sedangkan y adalah hasil belajar fisika. Setelah dilakukan uji hipotesis, maka dilakukan uji keberartian korelasi untuk melihat apakah koefisien korelasi berarti atau tidak. Pengujian dilakukan dengan menggunakan statistik t, yaitu,

$$
t=\frac{r_{x y} \sqrt{n-2}}{\sqrt{1-r_{x y}}}
$$


Dengan ketentuan, jika $t_{\text {hitung }}>\mathrm{t}_{\text {tabel }}$ dengan $\mathrm{dk}=\mathrm{n}-2$ dan $\alpha=0,05$ maka koefisien korelasi berarti dan jika $t_{\text {hitung }}<\mathrm{t}_{\text {tabel }}$ dengan $\mathrm{dk}=\mathrm{n}-2$ dan $\alpha=0,05$ maka koefisien korelasi tidak berarti.

\section{HASIL DAN PEMBAHASAN}

\section{Deskripsi Data}

Pada bagian ini akan dideskripsikan data hasil penelitian, yaitu yang berhubungan dengan jumlah waktu belajar fisika di luar jam sekolah dan hasil belajar fisika. Sesuai dengan hipotesis yang dikemukakan, variabel penelitian adalah jumlah jam belajar siswa di luar sekolah disimbolkan dengan notasi "x" dan hasil belajar fisika dengan notasi " $y$ ". Hubungan antara variabel $\mathrm{x}$ dan y digunakan rumus korelasi product moment. Hasil pengumpulan data terhadap variabel $\mathrm{x}$ dan variabel y dapat dilihat pada tabel 2 berikut ini,

Tabel 2 : Hasil Analisis Data Jumlah Jam belajar Siswa di Luar Sekolah dan Hasil Belajar Fisika di SMA Negeri 2 Mataram.

\begin{tabular}{ccc}
\hline No. & variabel $\mathrm{x}$ & Variabel $\mathrm{y}$ \\
\hline 1. & $\bar{x}=27,50$ & $\bar{y}=37,21$ \\
2. & $S=12,79$ & $s=16,86$ \\
3. & $\sum \mathrm{x}=1045$ & $\sum \mathrm{y}=1414$ \\
4. & $\sum \mathrm{x}^{2}=34797$ & $\sum \mathrm{y}^{2}=63140$ \\
5. & $\left(\sum \mathrm{x}\right)^{2}=1092025$ & $\left(\sum \mathrm{y}\right)^{2}=1999396$ \\
6. & $\sum \mathrm{x} y=46594$ & $\sum \mathrm{xy}=46594$ \\
\hline
\end{tabular}

\section{Analisis Data}

Angket yang disebarkan diperoleh data jumlah jam belajar siswa di luar sekolah (x) dan evaluasi didapatkan pula data tentang hasil belajar fisika siswa SMA Negeri 2 Mataram. Hubungan kedua variabel dilihat dengan menggunakan rumus korelasi product momet. Sebelum digunakan perlu dilakukan uji normalitas dan uji linieritas. Uji normalitas variabel $\mathrm{x}$ didapatkan nilai chi-kuadrat 4,94 lebih kecil dari chi-kuadrat tabel 11,1 berarti data variabel $\mathrm{x}$ terdistribusi normal. Uji normalitas variabel y didapat nilai chi-kuadrat 5,78 juga lebih kecil dari chi-kuadrat tabel 11,1 berarti data variabel y juga terdistribusi normal. Uji linieritas didapatkan $\mathrm{F}_{\text {hitung }}=1,19<\mathrm{F}_{\text {tabel }}=2,42$ maka persamaan regresi linier. Untuk uji keberartian regresi didapat $F_{\text {hitung }}=480,39$ dan $F_{\text {tabel }}=4,11$. Karena $F_{\text {hitung }}<F_{\text {tabel }}$ maka regresinya berarti.

\section{Uji Hipotesis}

Setelah dilakukan uji normalitas dan uji linieritas maka diketahui data terdistribusi norrmal dan persamaan regresi adalah linier. Hal ini menandakan bahwa semua syarat untuk menggunakan rumus korelasi product moment dipenuhi. Untuk menguji signifikansi koefisien korelasi product moment dari penelitian ini dibandingkan antara harga $r$ yang diperoleh melalui perhitungan dengan harga $\mathrm{r}$ pada tabel dengan taraf signifikansi $5 \%$. Didapatkan harga kritik $\mathrm{r}$ untuk taraf signifikansi 5\%, $\mathrm{n}=38$ adalah 0,32. Apabila $\mathrm{r}$ yang diperoleh dari hasil penelitian ini besar atau sama dengan 0,32 maka hipotesis nol ditolak dan sebaliknya jika $\mathrm{r}$ yang diperoleh kecil dari 0,32 berarti hipotesis nol diterima. Ternyata dari hasil penelitian ini didapatkan harga $r=0,96$ berarti harga $r_{\text {hitung }}$ lebih besar dari harga $r_{\text {tabel }}$ untuk taraf signifikansi 5\%. Untuk membuktikan koefisien korelasi yang didapatkan berarti atau tidak dilakukan pengujian koefiien korelasi dengan menggunakan statistik t. Melalui perhitungan didapatkan harga $t=20,57$. Ternyata $t_{\text {hitung }}$ lebih besar dari harga $t_{\text {tabel }}(20,57$ $>1,68$ ). Kesimpulannya adalah hipotesis kerja diterima yaitu terdapat hubungan yang berarti anatara jumlah jam belajar fisika di luar sekolah dengan hasil belajar fisika siswa SMA Negeri 2 Mataram. 


\section{Pembahasan}

Hasil penelitian menunjukkan terdapat hubungan yang berarti antara jumlah jam belajar fisika di luar sekolah dengan hasil belajar fisika siswa SMA Negeri 2 Mataram. Hal ini berarti jumlah jam belajar siswa di luar sekolah mempengaruhi hasil belajar fisika siswa. Hasil penelitian juga mendapatkan prosentase pengaruh waktu belajar di luar jam sekolah terhadap hasil belajar fisika siswa SMA Negeri 2 Mataram adalah 92,16\%. Sedangkan 7,84\% hasil belajar fisika siswa dipengaruhi oleh faktor lain. Berdasarkan teori waktu ideal untuk belajar di luar jam sekolah dalam satu hari adalah 4 jam (Slameto, 1989). Jadi selama angket disebarkan (45 hari) maka seharusnya jam belajar di luar sekolah yang dilakukan adalah $4 x 45=180$ jam. Sedangkan waktu belajar yang didapatkan dari penelitian 48 jam atau 26,7\% dari jam ideal. Tapi, jika dilihat untuk semua bidang studi di kelas XI, maka jam ideal itu dibagi 14 (banyaknya matapelajaran) sehingga untuk satu bidang studi didapatkan 12,857 jam atau 13 jam. Setiap bidang studi tidak sama tingkat kesukarannya dan matapelajaran fisika termasuk kategori yang sulit dan membutuhkan jumlah jam belajar yang lebih banyak (Hamalik, 1983), maka untuk prosentase di sini hanya dilihat dari satu matapelajaran saja yaitu fisika. Dari 38 sampel yang ditelitii, 2 orang mempunyai prosentase jam belajar di luar sekolah 26,7\% dari jam ideal keseluruhan. Prosentase jam belajar siswa di luar sekolah didapatkan yang terendah adalah 3,9\% dari jam ideal secara keseluruhan. Penelitian juga mendapatkan prosentase siswa belajar sendiri lebih besar dari siswa belajar terbimbing. Jadi besarnya pengaruh waktu belajar siswa diluar jam sekolah terhadap hasil belajar fisika, hal itu menjadi penyebab rendahnya hasil belajar fisika siswa SMA Negeri 2 Mataram. Berdasarkan analisis deskriptif yang telah dilakukan ternyata hipotesis nol $\left(\mathrm{H}_{\mathrm{o}}\right)$ yang penulis kemukakan secara statistik telah teruji ketidakbenarannya atau ditolak., sehingga penulis dapat memprediksi bahwa siswa yang mempunyai waktu belajar di luar jam sekolah banyak akan memperoleh hasil belajar yang baik pula. Olehkarena itu dapat dikatakan bahwa waktu belajar siswa di luar jam sekolah dengan hasil belajar fisika di SMA Negeri 2 Mataram mempunyai korelasi yang positif dan berarti untuk signifikansi 5\% dan taraf kepercayaan 95\%. The Liang Gie (2000) mengelompokkan waktu rata-rata setiap hari yang dimiliki oleh seorang siswa sebagai berikut : 8 jam untuk tidur, 3 jam untuk pemeliharaan diri, 2 jam untuk keperluan pribadi dan urusan kemasyarakatan, serta 11 jam sebagai sisa khusus untuk belajar. Dari pengelompokan waktu yang digunakan untuk belajar pada saat jam sekolah sebanyak 7 jam dan sisanya 4 jam digunakan untuk belajar di luar jam sekolah atau di rumah. Sawitri (dalam Kase, 2005) berpendapat bahwa teknik belajar dengan sistem kebut semalam sudah tidak tepat lagi bagi seorang siswa dalam mempelajari berbagai mata pelajaran. Syahrial A. (1994) mengemukakan bahwa belajar semalam suntuk adalah belajar mati-matian untuk memenuhi dan memadatkan kepalanya dengan berbagai macam mata pelajaran dalam waktu yang pendek dan mendesak. Delapan usaha semacam ini biasanya dilakukan oleh anak yang relatif malas. Untuk menguasai materi pelajaran, siswa harus memanfaatkan waktu belajar di rumah dalam kisaran 3-4 jam setiap hari. Waktu belajar itu digunakan untuk mengulang pelajaran, melengkapi, dan menyempurnakan materi pelajaran yang diberikan guru di kelas dengan bahan-bahan dari literature yang dianjurkan guru. Dilihat dari jumlah jam yang ditetapkan sepertinya terasa terlampau lama, namun bila dicermati dengan jumlah jam dalam satu hari sebanyak 24 jam, maka akan diperoleh rincian pemanfaatan waktu yaitu; 7-8 jam diperlukan untuk tidur demi kebugaran fisik, sisa waktu 16 jam pemanfaatannya : 6-8 jam dihabiskan di sekolah, 2-3 jam untuk mandi, makan, dan santai sepulang dari sekolah, sehingga masih tersisa 1-2 jam untuk membaca Koran, menonton TV, sehingga dapat disimpulkan bahwa kewajiban belajar selama 3-4 jam bukanlah hal yang berat untuk dijalankan. Apabila waktu belajar di luar jam sekolah ini dapat efektif digunakan oleh siswa jelas akan memberikan konstribusi positif pada hasil belajar siswa. Kontrol guru dan orang tua sangat dibutuhkan, berikutnya bimbingan orang tua dan guru juga menjadi faktor lain sebagai penentu keberhasilan siswa dalam melakukan belajar di luar jam sekolah. 


\section{KESIMPULAN}

Berdasarkan hasil analisis data dan pembahasan yang telah dilakukan, maka dapat disimpulkan, 1) terdapat hubungan yang berarti antara jumlah jam belajar fisika di luar sekolah dengan hasil belajar fisika siswa kelas MIPA7 SMA Negeri 2 Mataram, 2) Pengaruh waktu belajar di luar jam sekolah terhadap hasil belajar fisika adalah 92,16\% dan 7,84\% dipengaruhi oleh faktor lain, 3) prosentase waktu belajar siswa secara mandiri lebih besar dari pada prosentase belajar siswa secar terbimbing. Dengan demikian dapat dikatakan bahwa keberhasilan siswa dalam belajar fisika ditentukan oleh waktu belajarnya di luar jam sekolah. Waktu belajar di luar jam sekolah merupakan salah satu indikator yang dapat digunakan untuk memprediksi keberhasilan siswa dalam belajar fisika.

\section{SARAN}

Hasil penelitian menemukan bahwa waktu belajar di luar jam sekolah sangat mempengaruhi hasil belajar fisika siswa SMA Negeri 2 Mataram, olehkarena itu disarankan, 1) guru agar memberikan petunjuk, jalan dan nasehat kepada siswa bahwa waktu belajar di sekolah saja tidak cukup untuk memberikan hasil yang diharapkan, untuk itu harus ditambah dengan waktu belajar di luar jam sekolah, 2) Siswa diharapkan dapat menambah pengetahuan supaya mendapat hasil yang diharapkan.

\section{UCAPAN TERIMA KASIH}

Terima kasih tim ucapkan kepada LPPM Universitas Mataram yang sudah memberikan kemudahan dan fasilitas kepada tim selama proses penelitian berlangsung. Ucapan terima kasih juga tim sampaikan kepada kepala sekolah SD Negeri 6 Mataram, guru dan siswa yang sudah terlibat aktif dalam penelitian ini. Akhirnya, semoga penelitian ini bermanfaat bagi masyarakat sekolah dan lainnya

\section{DAFTAR PUSTAKA}

Afifah, G. (1994). Hubungan Waktu Belajar di Luar Jam Sekolah dengan Hasil Belajar Fisika. Padang. IKIP Padang Press.

Arif furkan. (1982). Pengantar Penelitian dan Pendidikan. Surabaya: Usaha Nasional.

Djamarah. 2005. Guru dan Anak Didik Dalam Interaksi Edukatif, Suatu Pendekatan Teoritis Psikologis. Jakarta. Rineka Cipta.

Ismayawati, B. 2016. Pengaruh Model Pembelajaran Berbasis Masalah (PBM) dalam Setting Pembelajaran Kooperatif Tipe TGT dan GI terhadap Kemampuan Berpikir Kritis dan Hasil Belajar Kimia Peserta Didik SMA N 1 Aikmel. Jurnal Penelitian Pendidikan IPA, 2(1), 54-65

Klinger. Walter. 1997. "Survei Metode Pengajaran dalam Ilmu Pengetahuan Alam" Erziehungswiss, Fakultat der Universtat, Erlangen-Nurnbe

Hilmi, N. 2017. Pengaruh Model Pembelajaran Discovery dengan Pendekatan Saintifik dan Keterampilan Proses terhadap Hasil Belajar Peserta Didik. Jurnal Penelitian Pendidikan IPA, 3(2), 1-7

Huda. M. 2013. Model Model Pengajaran dan Pembelajaran Isu-Isu Metodis dan Pragmatis. Yogyakarta. Pustaka Pelajar 
Muh, Makhrus. 2019. Analisis Rencana Pelaksanaan Pembelajaran (RPP) terhadap Kesiapan Guru sebagai "Role Model" Keterampilan abad 21 pada Pembelajaran IPA SMP. Jurnal Penelitian Pendidikan IPA, 5(1), 66-108

Marthen Kanginan. (2019). Fisika untuk SMA/MA Kelas XI. Jakarta. Penerbit Erlangga

Slameto. (1989). Faktor-Faktor yang Mempengaruhi Belajar. Bandung: Tarsito.

Sudjana. (1989). Teknik Analisis Regresi dan Korelasi. Bandung: Tarsito

Sugiyono. (2013). Metode Penelitian Kuantitif Kualitatif dan R\&D. Bandung. Alfabeta

Sawitri. (2005). Belajar Efektif. Jakarta. Universitas Terbuka Press.

Syahrial, A. (1994). Perbandingan Pengajaran $2 \times 3$ dengan Pembelajaran $3 \times 2$ di SMA Negeri 5 Padang. Padang. IKIP Padang Press.

The Liang Gie. (2000). Cara Belajar yang Baik. Yogyakarta. Gadjah Mada University Press 